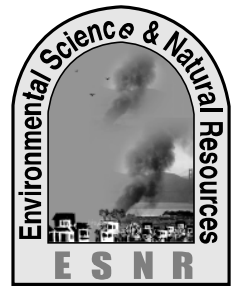

\title{
Effect of Ipns With Cowdung Bio-Slurry on The Performance of Water Melon in Ganges Tidal Floodplain
}

\author{
M. M. Hossain ${ }^{1}$, M. M. Howlader ${ }^{2}$, M. H. Rahman ${ }^{3}$ and M. R. Khatun ${ }^{4}$ \\ ${ }^{1,2}$ On-Farm Research Division, BARI, Khulna, ${ }^{3}$ Agronomy division, RARS, BARI, Jessore \\ ${ }^{4}$ Agricultural Training Institute, Daulatpur, Khulna
}

\begin{abstract}
The experiment was conducted in medium highland at Dacope, Khulna during rabi season of 2010-11. The aim of the study was to observe the effect of integrated use of bio-slurry along with inorganic fertilizer on the performance of water melon grown in AEZ 13. The experiment was laid out in a randomized complete block design with four replications. Three fertilizer doses viz. $\mathrm{T}_{1}$ : Soil test based inorganic fertilizer dose for high yield goal (HYG), $\mathrm{T}_{2}$ : Cowdung bio-slurry @ 5t/ha + IPNS basis inorganic fertilizer dose for high yield goal and $\mathrm{T}_{3}$ : Farmers' practice (average of 20 farmers surveyed) were taken as treatment. Results showed that yield and yield contributing characters of water melon were significantly influenced by the treatments. The highest fruit yield (44.50 t/ha) was recorded in cowdung bio-slurry@ $5 \mathrm{t} / \mathrm{ha}+$ IPNS basis inorganic fertilizer dose ( $\left.\mathrm{T}_{2}\right)$ followed by $\mathrm{T}_{1}(40.27 \mathrm{t} / \mathrm{ha})$. The lowest yield (35.20 t/ha) was obtained from farmers' practice. Economic analysis also revealed that the gross return (Tk. 534000.00/ha) and gross margin (Tk. 427515.00/ha) were higher in $\mathrm{T}_{2}$. Benefit-cost ratio (BCR) was also higher in $\mathrm{T}_{2}(5.01)$.
\end{abstract}

Key word: BCR, Cowdung bio-slurry, IPNS, STB, Water melon

\section{Introduction}

Depletion of soil organic matter is a major constraint for higher crop productivity in Bangladesh. A soil should have organic matter content of at least $3.5 \%$ (BARC, 2005). But in Bangladesh, most soils have less than $1.7 \%$ and some soils have less than $1 \%$ organic matter. The average organic matter content of top soils has been declined by $20-46 \%$ over past 20 years due to intensive cropping without inclusion of legume crops, imbalance use of fertilizers, use of modern varieties and scanty use of manure. So gradually degradation of soil fertility status of the country is now becoming a crucial issue. Bhuiyan (1991) reported that yield of several crops were declining in some soils. So the maintenance of organic matter is a burning issue both for the farmers and agricultural scientists. Biogas is now very much popular in Bangladesh due to high cost of fuel. Huge amount of bio-slurry comes out from this plant and it can be used as an excellent organic fertilizer. Bioslurry improves the physical, chemical and biological quality of soil besides providing both macro and micro-nutrients to crops. It also improves water holding capacity, cation exchange capacity, lesser soil erosion and provision of nutrients to plant and soil micro-flora including $\mathrm{N}$ fixing and phosphorus solubilizing organisms. In addition bio-slurry is free of weed seeds.

Balanced fertilization is a prerequisite for exploiting optimum yield potentials of high yielding crops. The beneficial effect of organic manure in crop production has been demonstrated by many workers (Joshi et al., 1994; Batsai et al., 1979; Singh et al., 1970 and Subhan, 1991). Many crops are grown in Bangladsh. But research work on the use of bio-slurry for water melon production is lacking in our country. Thus the experiment was undertaken to observe the effect of integrated use of bio-slurry along with inorganic fertilizers on the performance of water melon grown in AEZ 13.

\section{Materials and Methods}

The experiment was conducted at farmer's field of Dacope, Khulna under Ganges Tidal Floodplain (AEZ 13) during the rabi season of 2010-11 to find out the effect of integrated use of properly managed bioslurry along with inorganic fertilizer on the performance of water melon. Before conducting the experiment, nutrient package for each treatment was calculated. For this soil sample was collected from the selected land and analyzed at Soil Resources Development Institute (SRDI) laboratory, Daulatpur, Khulna. The experiment was conducted in RCBD with four replications. There were three treatments viz. $\mathrm{T}_{1}$ : Soil test based (STB) inorganic fertilizer dose for high yield goal (HYG), $\mathrm{T}_{2}$ : Cowdung bioslurry @ $5 \mathrm{t} / \mathrm{ha}+$ IPNS basis inorganic fertilizer dose for HYG and $T_{3}$ : Farmers' practice (average of 20 farmers). World queen was used as water melon variety. Unit plot size was $6.0 \mathrm{mX} 4.0 \mathrm{~m}$. The initial soil nutrient status of the experimental plot was presented in Table 1. 
Table 1. Initial nutrient status of the experiment soil

\begin{tabular}{|c|c|c|c|c|c|c|c|c|c|}
\hline Elements & $\mathrm{N}(\%)$ & $\begin{array}{l}\mathrm{P}(\mathrm{g} / \mathrm{g} \\
\text { soil) }\end{array}$ & $\begin{array}{l}\text { K } \\
\text { (m. eq/ } \\
100 \text { g soil) }\end{array}$ & $\begin{array}{l}\mathrm{S}(\mathrm{g} / \mathrm{g} \\
\text { soil) }\end{array}$ & $\mathrm{Zn}$ (g/g soil) & B (g/g soil) & $\begin{array}{l}\text { Salinity } \\
(\mathrm{dS} / \mathrm{m})\end{array}$ & $\mathrm{OM}(\%)$ & $\mathrm{p}^{\mathrm{H}}$ \\
\hline Soil test value & 0.143 & 10.00 & 0.49 & 110.53 & 5.33 & 1.16 & 0.70 & 2.46 & 4.7 \\
\hline Interpretation & Low & Low & Very high & Very high & Very high & Very high & $\begin{array}{l}\text { Non- } \\
\text { saline }\end{array}$ & Medium & $\begin{array}{l}\text { Highly } \\
\text { acidic }\end{array}$ \\
\hline
\end{tabular}

Nutrients NPK supply from 1 (one) ton materials of cowdung bio-slurry were $4.5,1.5$ and $5 \mathrm{Kg}$, respectively (BARC, 2005). Based on this, the IPNS basis inorganic fertilizer dose were calculated for $\mathrm{T}_{2}$ treatments. Various levels of chemical fertilizer comprising the treatments were used in this trial (Table 2).

Table 2. Fertilizer doses of different treatments for cultivation of water melon

\begin{tabular}{|c|c|c|c|c|c|c|}
\hline \multirow[t]{2}{*}{ Treatments } & \multicolumn{5}{|c|}{ Nutrients $(\mathrm{Kg} / \mathrm{ha})$} & \multirow[t]{2}{*}{ CD slurry $(\mathrm{Kg} / \mathrm{ha})$} \\
\hline & $\mathrm{N}$ & $\mathrm{P}$ & $\mathrm{K}$ & $\mathrm{S}$ & $\mathrm{Zn}$ & \\
\hline $\mathrm{T}_{1}$ & 97 & 32 & 11 & 4 & - & - \\
\hline $\mathrm{T}_{2}$ & 74 & 24 & - & 4 & - & 5000 \\
\hline $\mathrm{T}_{3}$ & 92 & 35 & 125 & 18 & 1 & - \\
\hline
\end{tabular}

Cowdung and all of TSP, MoP, gypsum and half of urea were applied at the final land preparation as per treatment. Rest of urea was side dressed equally at three splits at 15 DAS, flowering and fruiting stage. Seeds of water melon were sown on 14 January, 2011 with the spacing of $2 \mathrm{~m} \times 2 \mathrm{~m}$. Intercultural operations viz. weeding, irrigation and spraying insecticides were done as and when required in order to support normal growth and development of water melon. The crop was harvested on 10 April, 2011 after full of maturity. Prior to harvest five plants were selected randomly from each plot carefully for collecting data on yield and yield contributing characters. The collected data were analyzed statistically following the ANOVA technique with the help of MSTAT -C programme. The mean differences among the treatment means were adjudged by Least Square Difference test (Gomez and Gomez, 1984).

\section{Results and Discussion}

Yield and yield contributing characters of water melon differed significantly due to different nutrient management packages (Table 3). The highest fruit yield (44.50 t/ha) was obtained from IPNS with $5 \mathrm{t} / \mathrm{ha}$ cowdung manure management. The cumulative effect of fruit length $(33.52 \mathrm{~cm})$, fruit diameter $(21.09 \mathrm{~cm})$ and individual fruit weight $(3.60 \mathrm{Kg})$ might be contributed to increase yield in $\mathrm{T}_{2}$ fertilizer management. Jayakumar and Elanogovan (1993) found that biogas slurry @ $300 \mathrm{~g} / \mathrm{plot}$ produced the largest head of sunflower. Similarly applications of biogas slurry increased cob yield of maize were reported by Manna and Hazra (1996). Batsai et al. (1979) reported that chemical fertilizers along with organic manure produced the highest cabbage yield. The highest number of fruits per plant (3.66) was found from the treatment $T_{3}$ which was statistically similar with treatment $T_{2}$. The second highest yield (40.27 t/ha) attained from $T_{1}$ i.e. soil test based inorganic fertilizer dose for high yield goal over the yield of farmers practice.

Table 3. Effect of cowdung bio-slurry on the yield and yield contributing characters of water melon during rabi season, 2010-11

\begin{tabular}{lllllll}
\hline Treatments & Plant ht. $(\mathrm{cm})$ & $\begin{array}{c}\text { Fruit length } \\
(\mathrm{cm})\end{array}$ & $\begin{array}{c}\text { Fruit diameter } \\
(\mathrm{cm})\end{array}$ & $\begin{array}{c}\text { Fruit/plant } \\
(\text { no. })\end{array}$ & $\begin{array}{c}\text { Individual fruit wt. } \\
(\mathrm{Kg})\end{array}$ & Yield (t/ha) \\
\hline $\mathrm{T}_{1}$ & 2.60 & 31.42 & 20.02 & 3.00 & 3.12 & 40.27 \\
$\mathrm{~T}_{2}$ & 2.65 & 33.52 & 21.09 & 3.50 & 3.60 & 44.50 \\
$\mathrm{~T}_{3}$ & 2.62 & 31.42 & 20.00 & 3.66 & 3.22 & 35.20 \\
\hline LSD $(0.05)$ & 0.50 & 1.15 & 0.83 & 0.26 & 0.27 & 5.29 \\
$\mathrm{CV}(\%)$ & 3.03 & 1.58 & 1.25 & 6.42 & 3.5 & 7.76 \\
\hline
\end{tabular}

$\left(\mathrm{T}_{1}\right.$ : STB Inorganic fertilizer dose for HYG, $\mathrm{T}_{2}$ : Cowdung bio-slurry @ $5 \mathrm{t} / \mathrm{ha}+$ IPNS basis inorganic fertilizer dose for HYG and $\mathrm{T}_{3}:$ Farmers practice) 
Table 4. Benefit- cost ratio analysis of water melon under different treatments

\begin{tabular}{lccccc}
\hline Treatments & Yield (t/ha) & $\begin{array}{c}\text { Gross return } \\
\text { (Tk./ha) }\end{array}$ & $\begin{array}{c}\text { Total variable cost } \\
\text { (Tk./ha) }\end{array}$ & Gross margin (Tk./ha) & BCR \\
\hline $\mathrm{T}_{1}$ & 40.27 & 483240.00 & 102395.00 & 380845.00 & 4.82 \\
$\mathrm{~T}_{2}$ & 44.50 & 534000.00 & 106485.00 & 427515.00 & 5.01 \\
$\mathrm{~T}_{3}$ & 35.20 & 422400.00 & 112450.00 & 309950.00 & 3.76 \\
\hline
\end{tabular}

Price (Tk./Kg) : Cowdung slurry 1, Urea 12, TSP 22, MoP 15, Gypsum 6, Zinc sulphate 130, water melon 12 and Labour Tk. 200/M/D

\section{Cost and return analysis}

Regarding economic performance, the highest gross return (Tk. 534000.00/ha) and gross margin (Tk. 427515.00/ha) were recorded in IPNS with 5 t/ha cowdung bio-slurry. The highest BCR (5.01) was also calculated from the treatment $T_{2}$.

\section{Conclusion}

The yield performance of water melon under IPNS with cowdung bio-slurry management was better. But the residual effect and its impact on soil health is deemed important. Cost and return analysis also revealed that the highest gross return and gross margin as well as BCR was calculated from the same treatment $\left(\mathrm{T}_{2}\right)$ i.e. IPNS with $5 \mathrm{t} / \mathrm{ha}$ cowdung bioslurry management. So integrated plant nutrient system with cowdung bio-slurry could be suggested for the production of water melon.

\section{References}

BARC (Bangladesh Agricultural Research Council). 2005. Fertilizer Recommendation Guide2005.

Batsai, S. T.; Polyakev A. A. and Nedbal, R. F.1979. Effect of organic and mineral fertilizers on the yield and quality of irrigated late and white cabbage in the steppe region of the crimea. Hort. Abst., 49 (11): 730
Bhuiyan, N. I. 1991. Issues concerning declining/stagnating productivity in Bangladesh Agriculture. A paper presented at the National Workshop on Risk Management in Bangladseh Agriculture, held at BARC. Dhaka. Bangladesh, August, 1991. 24-27

Gomez, K. A. and Gomez, A. A.1984. Statistical Procedures for Agricultural Research. $2^{\text {nd }}$ edn. John Wiley and Sons. New York. pp 207-215

Jayakumar, M.; Eyini, M. and Elanogovan, R. 1993. Effect of biogas slurry on salinity-induced changes in growth and yield of sunflower. Indian J. Agril. Sci., 63 (10): 655-657

Joshi, J. R; Moncrief J. F; Swan J. B. and Malzer G. L. 1994. Soil Till. Res., 31: 225

Manna, M. C. and Hazra, J. N. 1996. Comparative performance of cowdung slurry, microbial inoculums and inorganic fertilizers on maize. J. Indian Soc. Soil Sci., 44: 526-528

Singh, K.; Gill, J. S. and Verma, O. P. 1970. Studies on poultry manure in relation to vegetable production. Indian J. Hort., 27: 42-47

Subhan. 1991. Effect of organic materials on growth and production of cabbage. (Brassica oleracea L). Soils and Fert., 54 (4): 587 